\title{
Martem Accendere Cantu: The Meaning of Music on the Battlefield
}

(on Phld. Mus. 4.LXVIII.33-40, LXIX.7-12 Delattre = P.Herc. 1578/17 N, 1575/18 N)

\section{Abstract}

This paper examines in detail an under-appreciated passage from Philodemus of Gadara's On Music in order to elucidate several important controversies in Hellenistic musical philosophy. The Stoic Diogenes of Babylon claimed that the emotional impact of trumpet tunes can inspire soldiers to fight. But the Epicurean Philodemus believed that the meaningful words ( $\lambda$ ó $o \imath$ ) which stimulate our actions are utterly distinct from meaningless musical sound ( battlefield function not as music but as a kind of makeshift language, using conventional signifiers to communicate instructions. I show how both philosophers' views arise logically out of doctrines from their respective schools. I then argue that the trumpet's dual status as both performance instrument and communications device makes it a natural philosophical flashpoint: it raises central questions about what music is, how it affects listeners, and whether it can convey meaning.

$\tilde{\eta} \theta$ o $\varsigma$ theory — Epicureanism - Stoicism - ear and mind — music semiotics - musical psychology

\section{$1 \quad$ Music at war: what is it good for?}

There is a story which goes like this: in the middle of a battle there is a company of Italian soldiers in the trenches, and an Italian commander who issues the command, 'Soldiers, attack!' He cries out in a loud and clear voice to make himself heard in the midst of the tumult, but nothing happens, nobody moves. So the commander gets angry and shouts louder: 'Soldiers, attack!' Still nobody moves. And since in jokes things have to happen three times for something to stir, he yells even louder: 
'Soldiers, attack!' At which point there is a response, a tiny voice rising from the trenches, saying appreciatively 'Che bella voce!' 'What a beautiful voice!'

— Mladen Dolar, A Voice and Nothing More, p. 3.

A war zone is no place for musical displays, and yet there they are. Or at least, there they were on the ancient battlefield: pipes, trumpets, dances, all sharing space with and even participating in the unforgiving melee. The phenomenon is so ubiquitous in our sources that we can become desensitised to the sheer incongruity of the thing. But there is surely a mismatch between, say, the $\alpha \dot{\lambda} \lambda$ ó $\varsigma$ — whose sound was perhaps best appreciated at leisure after a full $\kappa \hat{\lambda} \lambda \xi \xi$ or two — and the scenes of carnage which $\alpha \hat{\lambda}$ ó $\varsigma$-music sometimes accompanied.

One question which therefore arises is whether hearing music on the battlefield was in any way the same kind of experience as hearing it at a symposium, or for that matter on a concert stage. Different authors will give you different answers. Thucydides writes that the Spartans used pipe-playing for purely functional purposes, to keep their soldiers stepping in time. ${ }^{1)}$ But Aulus Gellius thought that more than just ambulatory discipline was at stake: in Attic Nights, the same Spartan $\alpha$ $\lambda \hat{\lambda}$ ó described by Thucydides is said to benefit morale as well, in that it steadies the hearts of the fighters who hear it so they can make an orderly charge. ${ }^{2)}$ In Thucydides, the music's purpose is to disseminate information about when to step, and the fact that it may in other contexts be used to excite emotion or generate aesthetic pleasure is pretty much irrelevant. For Gellius, though, the music which the Spartans play on

\footnotetext{
1) Thuc. 5.70 .

2) Gel. 1.11.1-4.
} 
the march is fundamentally the same emotionally and psychologically affecting art form that Pythagoras (or Damon, or whoever) was supposed to have used to calm the rambunctious energy of drunken youths. ${ }^{3)}$ This seems like a significant disagreement: it is not entirely clear how, in the end, we are to regard the instruments of war. Are they mere technological conveniences, or sources of genuine musical expression?

There is a passage in Philodemus which speaks to this question. It has not yet received the attention it deserves for what it can tell us about the nature of music in Greek thought. Undoubtedly this is in part because the prospect of fighting one's way through Philodemus' charred and mangled prose — which would be somewhat tortured even if it were pristinely preserved — has all the appeal of a root canal for many scholars. I therefore hope that, before I turn to the relevant passage, readers will forgive a brief reminder about who and what is under discussion here.

The doctrinaire Epicurean Philodemus wrote in Greek about the Hellenic philosophical tradition, but often for the benefit of Rome's luminaries in the first century BC. ${ }^{4)}$ In each treatise he constructs a kind of intellectual history of his topic by quoting liberally those who have addressed it before him, excoriating them for their errors, and

${ }^{3)}$ See further Matelli 2004, esp. 160f on this anecdote and its various protagonists at e.g. Iamb. VP 25.112-5; Sext. Emp. M. 6.7.1-9.1; Cic. Consil. fr. 3 (=Opera iv.3, p. 339 Müller); Plu. De Isid. 384a2-5; Ath. Deip. 623f-4b; [Plu.] De Mus. 1146b-c; Galen PHP 5.6.21-2 (= Damon B7 Wallace); Mart. Cap. 9.926 (= Damon B8 Wallace).

4) On the literary and philosophical communities which passed through L. Calpurnius Piso's villa at Herculaneum see Gigante \& Capasso 1989, 3-6; Asmis 1992, 206, 227-30; Armstrong 2004, 2f.; Gigante 2004, 85-7. 
articulating his opposing views. ${ }^{5)}$ This is why the fourth and only extant book of On Music finds him attacking the musical philosophy of Diogenes of Babylon, the Stoic scholarch who participated in the philosophical embassy to Rome in $\left.155 .{ }^{6}\right)$ Philodemus cites Diogenes with withering disapproval, thus preserving fragments from the Stoic's corpus that would otherwise be lost. This is an irony to which Philodemus is prone.

\section{The claim: Philodemus contra Diogenes on trumpets}

The section of Philodemus' aesthetic writings I want to examine is On Music 4.LXVIII.33-40, LXIX.7-12 Delattre:

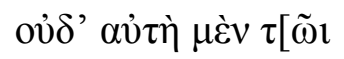

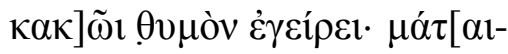

ov] $\gamma \grave{\alpha} \rho$ àv $\tau o ̀ v ~ \tau \tilde{\omega} v \sigma \alpha \lambda[\pi i ́ \gamma \gamma \omega v$

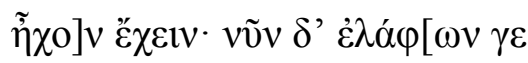

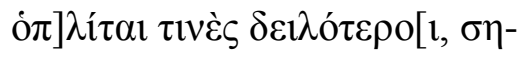

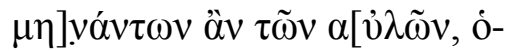

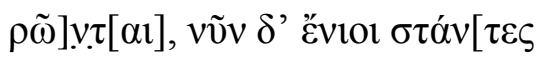

$\dot{\alpha} \tau \rho \varepsilon \mu] \varepsilon \grave{~ \kappa \alpha i ̀ ~} \pi \alpha \nu \tau \alpha \chi 0 \tilde{v}[\ldots$

$(\ldots)$

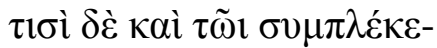

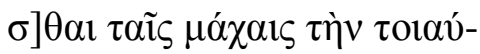

\footnotetext{
5) For a trenchant account of this 'hypomnematic' technique see Delattre 2007, XXVI-XXX.

6) On whose work and general philosophical commitments as they relate to music see Obbink \& Vander Waerdt 1991, 355-9; Janko 1992, 123-30; and below, pp. 6-12.
} 


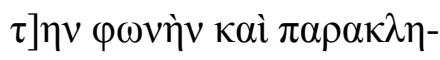

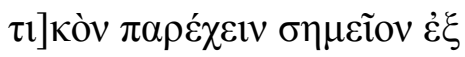

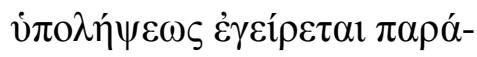

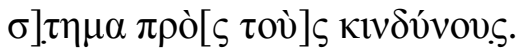

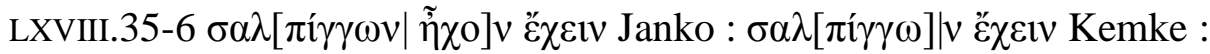

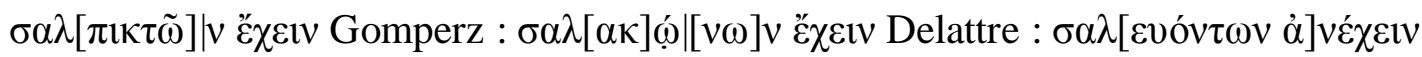
Angeli. ${ }^{7)}$

7) Throughout this paper, I use Delattre's 2007 text except at LXVIII.35-6, where I believe Janko's reading (refining those of Kemke and Gomperz) is correct. The drawings (disegni, designated $N$ ) which were made from these sections of P.Herc. 1578 and 1575 before those papyri were destroyed in the unrolling process, are reproduced on CD-ROM in Delattre's edition (see Janko 2000, 57f.; Angeli 2004, 11f. with n. 4; Delattre 2007, LXXXII-LXXXV, CXX, CXXIII). Janko's text fits equally well into the lacunae (cf. Delattre 1989, 63f.; Janko 1992, 124f.), and trumpets make more sense in the context of the argument than $\sigma \alpha \lambda[\alpha \kappa] \varphi \underline{\mid} \mid[v \omega] \nu$, braggarts (I also do not think there is cause to read traces of Omega here). I am intrigued but not convinced by Angeli's 2004, 14-8 reading, which fits the passage into Diogenes' broader views about the cultural value of music (cf. e.g. XXII.4-15). In order to accommodate $\sigma \alpha \lambda \varepsilon v o ́ v \tau \omega v$, Angeli has to read Delta at LXVIII.34 where there is almost certainly a Tau, and to make the grammar of the passage somewhat elliptical besides — see further below, pp. 16-18 with n. 42, on related issues with the philosophical argument itself. What seems certain to me is our topic, which is Diogenes' theory of musical leadership in wartime. 
It [sc. musical sound, $\dot{\eta} \mu$ ov would do no good whatsoever for such a man to experience the sound of the trumpets. As a matter of fact, some foot-soldiers show themselves to be more cowardly than deer when the pipes give the signal, while others stand their ground, unfazed no matter the circumstances (and ...). For certain people when they are locked in battle, a similar kind of vocal utterance also provides a stimulating sign arising out of judgment, and that too arouses resolve in the face of danger.

Though the evidence is fragmentary, the important starting point here is that Philodemus is clearly refuting Diogenes' assertions about the use of trumpet and pipe music in war

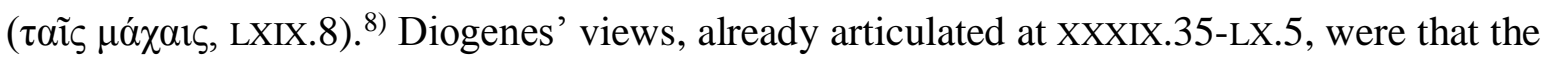

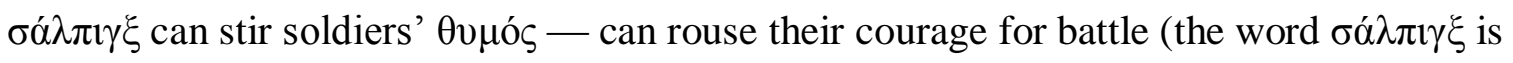
preserved in its entirety at XXXIX.41 and partially at 36). Diogenes adduced this example to

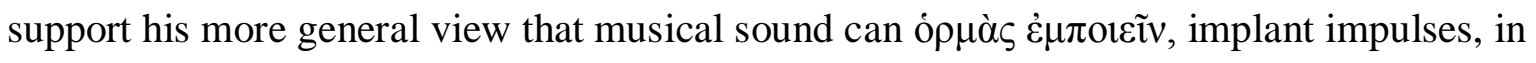
its listeners. ${ }^{9)}$ The opaque details of that process have been examined elsewhere more subtly than there is space to do here. ${ }^{10)}$ But broadly speaking, Diogenes drew from $\tilde{\eta} \theta$ o $\varsigma$ theory as expounded by Plato, whom he sometimes quoted. ${ }^{11)}$ For the Stoic, though, $\mu \varepsilon \dot{\lambda} \eta$ do not merely convey representations $(\mu \uparrow \mu \eta \dot{\sigma \varepsilon l \varsigma) ~ o f ~ p s y c h o l o g i c a l ~ d i s p o s i t i o n s ~ l i k e ~ b r a v e r y ~ o r ~}$

\footnotetext{
8) As outlined in Delattre 2007, 130-2. Cf. Gomperz 1885, 15.

9) See Phld. Mus. 4.LXXXIX.29-40; cf. XIV.

10) By Barker 2001, 362-5; Woodward 2010, esp. 236-45; and Kramarz 2016, 48f., 277-93.

11) See especially Phld. Mus. 4.LI.1-LII.3 with Pl. Lg. 669b5-e4, 802b1-c4; Rispoli 1974, 62-4; Delattre 2007, 82f. with notes.
} 
temperance, as they did for Plato. ${ }^{12)}$ Rather, songs actually are themselves temperate

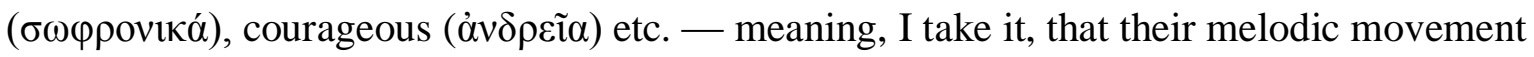
along the scale or rhythmic movement in time is identical with the movement of a soul undergoing emotional or desiderative affections, $\pi \alpha \dot{\theta} \eta \eta$, of the kind entailed in the relevant virtue. ${ }^{13)}$ It is important, if not uncontroversial, to note that Diogenes believes such properties belong to melody and rhythm even without words. ${ }^{14)}$ One main reason for thinking so is that in passages such as ours Diogenes attributes motivational powers to purely instrumental music: wordless trumpet tunes rouse courage and inspire martial valor.

These views about music which I have attributed to Diogenes would not have had to emerge out of thin air: they would likely have found stable grounding in Stoic physics and

12) On emotional states and ethical dispositions as psychological motions which may be mirrored or represented in musical motion, see e.g. P1. Lg. 653a5-4a7, 790d5-e4; Tim. 47d2e2, 80b6-8; Taylor 1928, 634 on Tim. 90c6-d7; Halliwell 1986, 118; Barker 1984-9, 2.53; Petraki 2008, 149, 157-65; Pelosi 2010, 66f., 81f.

13) See Phld. Mus. 4.XIX.45-XX.6; see further CXVII.23-34 with West 1992, 250; Barker 2001, 353; Woodward 2010, 240-4. Cf. [Arist.] Prob. 19.27 (=919b26-37), and see below, pp. 1112 , for an example of how this might work. The notion that music's expressiveness comes down to some form of melodic, rhythmic, or tonal movement is widespread in ancient and modern aesthetics (cf. Davies 1994, 229-40). A cogent defense of the idea that melodies may be said metaphorically to 'move' is Scruton 2009, 43-8 against Budd 2003. In his personal notes, Wittgenstein 1980, 51f. goes so far as to cite a section of music using only a linear shape, thus apparently attempting to represent the essence of the sound by tracing a graphic outline of its 'movement.'

14) So Scade 2017, 203 contra Nussbaum 1993, 103f., $116 f$. 
psychology. A principle of central importance here is that of the immanent $\lambda$ ó ${ }^{\circ} \varsigma$, a rationally comprehensible structure which pervades the entire universe. For Stoics the cosmos is a union of two things, separable conceptually but not in reality: inert matter and the divine organising principle or consciousness (voṽ $)$ which activates that matter and gives it form. ${ }^{15)}$ As a consequence the impressions made upon our minds and senses by the world around us (our $\varphi \alpha v \tau \alpha \sigma i \alpha \imath$ ) can already come formed according to a structure that is inherently rational. Some have gone so far as to argue that all human $\varphi \alpha v \tau \alpha \sigma i \alpha$ are of this kind. ${ }^{16)}$ But for our

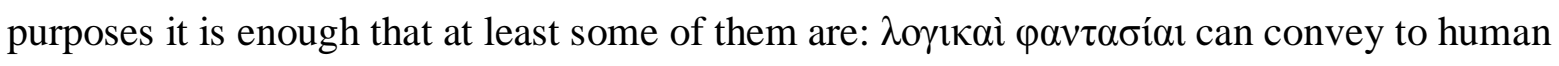
perception aspects of a rationally structured world. ${ }^{17)}$ We may be mistaken in our interpretation or understanding of that structure, but the fact remains that it is there for us to be mistaken about: when we perceive accurately and reason correctly, we are not so much bringing order to the world as discerning the order already present in it. ${ }^{18)}$

${ }^{15)}$ See esp. Diog. Laert. 7.137.9-39.11; Plot. Enn. VI.1.26-7; Philo, De Opificio Mundi 8.39.4 Cohn $(\approx S V F$ II.300, 302, 314, 315). For a further summary of some relevant sources see Kahn 1969, 168-71; Kerferd 1978, 251; Long \& Sedley 1987, 1.271; Algra 2003, 165-70; White 2003, 128-30; Gourinat 2009, 49-51.

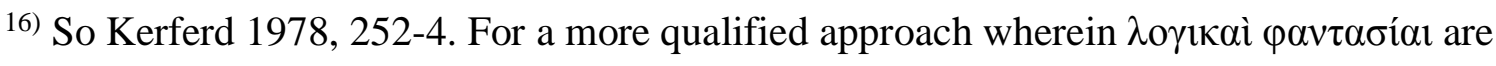
characteristic of rational animals but not the only kind they may experience, see e.g. Long 1971, 82f.; Togni 2013, 173.

17) See e.g. Diog. Laert. 7.50-1; Cic. Ac. 1.11.40-2; Aëtius 4.11, 12 apud [Plu.] Placita Philosophorum 900c4-14, 900d4-901a5; cf. [Galen] De Historia Philosophica apud ibid. 900b8-c10 (= FDS 255.14-37, 256, 268, 277.17-27, 277A.9-20).

18) Cf. Obbink 1999, 184-91; Ierodiakonou 2014, $438 f$. 


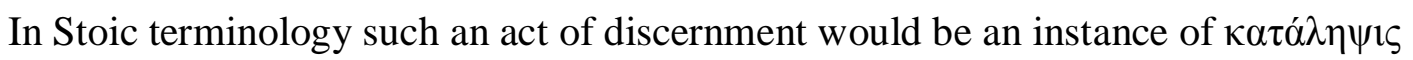
— this is the third of four cognitive faculties listed in a famous illustration attributed to Zeno

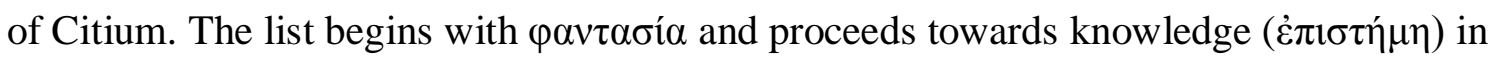
what might be called an increasing order of certainty or affirmation. First we merely experience a perception ( $(\alpha \nu \tau \alpha \sigma i ́ \alpha)$, then we recognise (or think we recognise) a correspondence between that perception and the outside world ( $\sigma \nu \gamma \kappa \alpha \tau \alpha \dot{\theta} \theta \varepsilon \sigma \varsigma)$. If we grasp

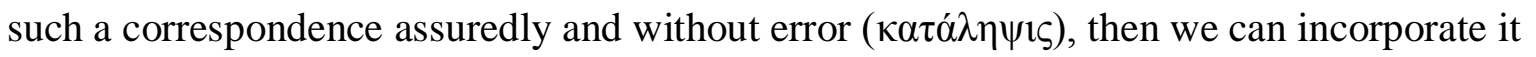
into a scheme of knowledge $(\dot{\varepsilon} \pi \imath \sigma \tau \eta \dot{\mu \eta}) .{ }^{19)}$

This very rough summary, though it skates over several ancient and modern disagreements in interpretation, is nevertheless enough to give an idea of what Diogenes probably thinks happens when we hear music. Those who listen to well-tuned melodies hear a series of successive tones. These tones all belong to the same scalar system, and so they are related to one another by a rational structure of intervals. Using the Stoa's language, then, we

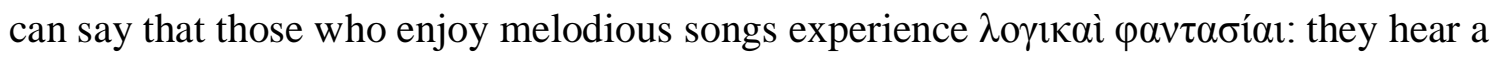
sequence of sounds in which can be discerned the rational structure, the $\lambda$ ó $\gamma \circ \varsigma$, which makes those sounds harmonious. It is worth noting that this view of music is consonant with the one adopted by Aristoxenus, whom Diogenes seems to have read and whose Elementa Harmonica provides the framework for thinking about musical structures in the way I am arguing Diogenes does. ${ }^{20)}$ The El. Harm. takes as an indispensable premise the claim that

${ }^{19)}$ Cic. Ac. 2.145 (= FDS 369.9-20). Cf. Sext. Emp. M. 7.151 (=FDS 370.4-10), and see further Kerferd 1978, 254-8; Long \& Sedley 1987, 1.256f.; Annas 1990, 186f.; Frede 1999, 297-300; Long 2002, 117f., 123.

${ }^{20)}$ On the connections between Diogenes and Aristoxenus see Brancacci 1996; Delattre 2007, 373 n. 2, 432 n. 8. 


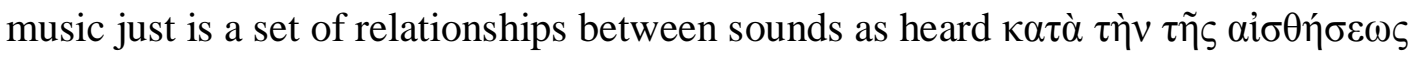

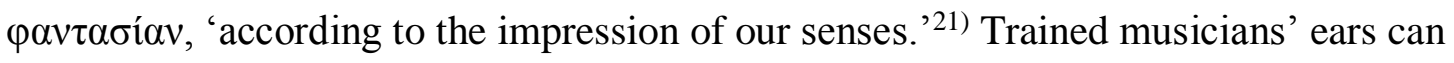
perceive the intelligible relationships which govern the composition of well-tuned songs and which inhere in the very sounds of those songs. Thus Diogenes is thought to be at his most Aristoxenean when he speaks of the 'definitions, distinctions, and demonstrations' which we encounter in harmonic science. ${ }^{22)}$ The Stoic thought that composers could grasp

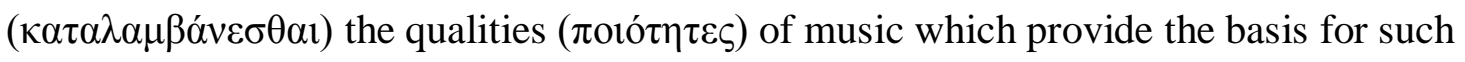

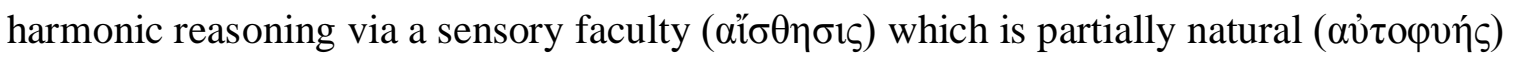

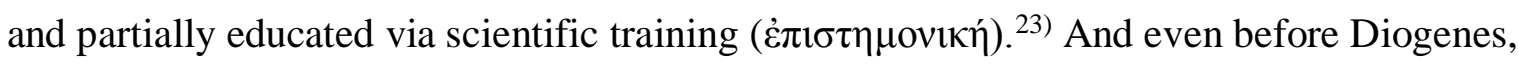
Zeno was rumored to have indicated that music is "what sound and tuning, gut and sinew,

${ }^{21)}$ See Aristox. El. Harm. 1.8.20-5, 1.9.2-4, and cf. 2.48.20-5 with further comments in Barker 1991, 204f.; 1984-9, 2.123f.; Levin 2007, 415.

${ }^{22)}$ Phld. Mus. 4.XLVIII.24-9:

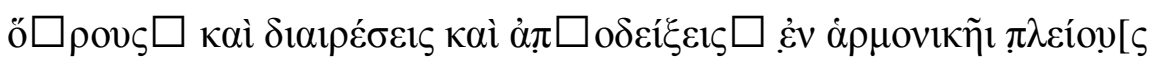
ยĩval] - cf. 4.CXXXV.26-8.

23) Phld. Mus. 4.CXV.26-35; cf. XXXIV.3-7. Diogenes is probably also influenced here by the Academic Speusippus, who formulated a similar view as a modification of Pl. Tim. 27d6-8a3 (see Sext. Emp. M. 7.145-6 with Delattre 1993, 70 n. 9, 84f.; 2007, 210 n. 1). But what

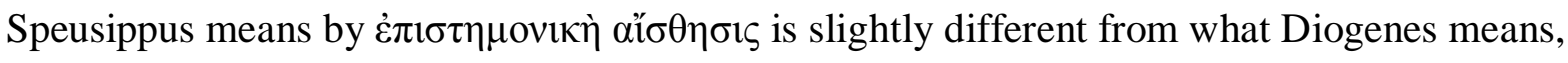
and the Academic's terminology at this point has been overlaid with Stoic vocabulary by a middle man, perhaps Antiochus of Ascalon. See Parente 1980, 242-6; Tarán 1981, 431-4; Kaklamanou 2012, 1185, 1189 n. 17. 
wood and bone produce when they partake of reason ( $\lambda$ ó $\gamma$ os), rhythm ( $\dot{\rho} v \mu \mu$ ó $\varsigma)$, and order $(\tau \alpha \dot{\xi} \xi 1 \zeta) .{ }^{, 24)}$

Thus both Diogenes' own tradition and the Elementa Harmonica would have furnished ample intellectual resources for arguing that music is a $\varphi \alpha v \tau \alpha \sigma i ́ \alpha$ conveying some

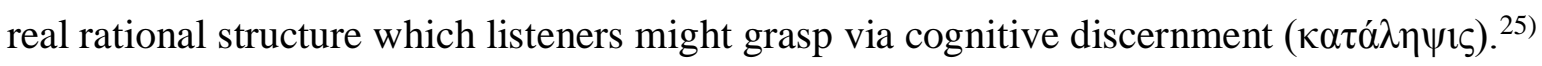
Perhaps such a $\lambda$ ófoৎ would need to be articulable in language (as a 'sayable,' a $\lambda \varepsilon \kappa \tau o ́ v) .{ }^{26)}$ But it would not itself need to be expressed in language any more than the proportion we discern in a well-built house, though it can be described with words, is itself made of words. Thus, for a Stoic, instrumental music could certainly contain within it structured movement akin or identical to that of a rational soul experiencing emotions and choosing actions.

It will be helpful to imagine how these rather abstract ideas might be cashed out in terms of the trumpet. Perhaps the notes of the Dorian mode are related to one another in a discernible rational structure, and perhaps when tunes move between those notes they move in the kind of way souls move when pursuing the noble and avoiding shame - that is, when performing various courageous actions. Then a particular trumpet tune could move with the same motion as that of a soul when (for instance) its owner charges into battle though outnumbered. An individual soldier hearing that tune would then grasp that motion via $\kappa \alpha \tau \alpha \dot{\lambda} \eta \psi 1 \varsigma$. If such grasping entails somehow receiving the relevant structure into one's own

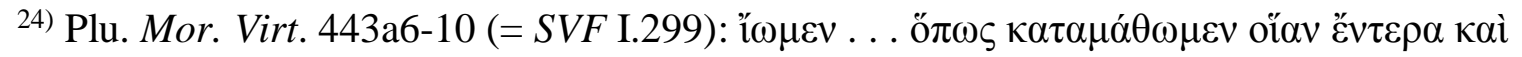

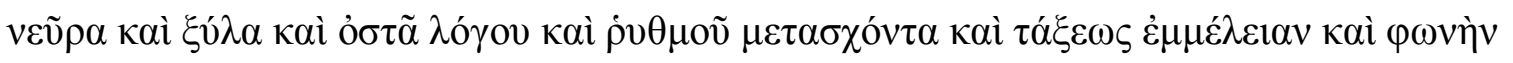
ạ̀ínбıv. Trans. modified from Scade 2017, following Helmbold.

25) Similarly Scade 2017, 214-16.

26) This may be suggested by e.g. Diog. Laert. 7.63.5-9; Sext. Emp. M. 8.70.2-74.5 (= FDS 696.10-15; SVF II.187); cf. Togni 2013, 173. 
soul (Zeno's image is that of a hand closing into a fist), then our soldier would, just by hearing the tune, be fired up with the precise kind of $\alpha v \delta \rho \varepsilon i ́ \alpha$ required to perform the charge himself. For a modern parallel we might imagine the tune of 'I Vow to Thee My Country,' when played rousingly on the trumpet, inspiring a private on the shores of Normandy to make the ultimate sacrifice.

This is all nonsense according to Philodemus, primarily because Epicurus asserted

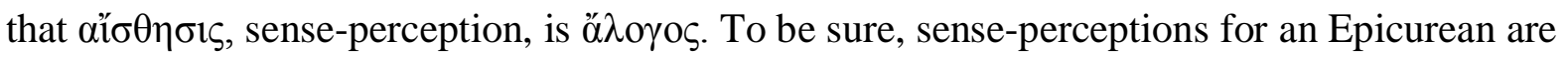
also $\dot{\alpha} \lambda \eta \theta \varepsilon \tilde{i} \varsigma$, true. But this can only mean that when we have a perceptual experience like hearing a sound, we can know for certain a) that we have that experience, and b) that the quality of that experience, given the healthy operation of our faculties, conveys a reality about the outside world and a stable basis for further reasoning. By contrast that reasoning itself — any inference we may draw from our perceptions, and any decision we may freely choose to make as a result of such an inference — is a function of our rational mind, an operation of $\lambda$ ó $\gamma \circ \varsigma$ wholly distinct from the mere irrational fact of our sensory experience. ${ }^{27)}$ For Philodemus this implies a stark divide between two widely discussed faculties of musical

27) On the truth of sense-perceptions see e.g. Plut. Adv. Col. 1109a8-c4; Sext. Emp. M. 7.2034; Cic. Luc. 25. On their irrationality and our application of rational thought to them see Diog. Laert. 10.31-2; Ep. ad Her. 38-9. On the complex interpretative issues surrounding the claims I have made here see esp. Striker 1977, 128-42; Long \& Sedley 1987, 1.85f., 94f.; Everson 1990, 169-81; Asmis 1999, 266-71; O’Keefe 2014, 462f.; Hahmann 2015, 277-301 with further bibliography at 271-6. 


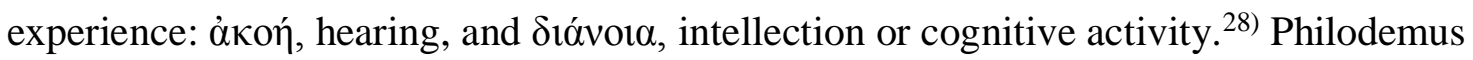
thinks melodic and rhythmic sounds are mere sensory experiences, perceptual events which can cause pleasure but cannot of themselves generate rational judgments or decisions (such as the decision to charge into battle). ${ }^{29)}$ If a sound — such as that of spoken language — does influence our thoughts, what causes that is not the sound itself but the content semantically encoded within it. ${ }^{30)}$

Philodemus therefore wants to enforce an impermeable boundary between hearing melodic and rhythmic sound, a naked fact of perception which may delight us as tasty food

${ }^{28)}$ The interrelation of these two faculties in musical experience is perhaps most elaborately described in our ancient sources by Aristoxenus — see e.g. Aristox. El. Harm. 33.4-8, 46.2450.14 with Barker 1991, 211-4; 2005, 163-5.

${ }^{29)}$ Halliwell 2002, 256f. has noted the similarity between this Philodemean position and Eduard Hanslick's 1922, 1-20, 43-8 et passim denial that music expresses anything other than itself. It may be added that Diogenes, by contrast, belongs to a line of theorists who see in music some structural resemblance to features of emotions (like soul-movements) or to things generated by emotions (like physical gesture). That line stretches not only backwards to Plato but also forwards to the likes of Langer 1941, 167-93; Kivy 1980, 54-6, 83; Davies 1994, 228-9; Robinson 2005, 310-21 — although some (like Plato, Diogenes, and Robinson) think music acquires these resemblances because it genuinely communicates some real emotion, while others (like Kivy and Davies) think expressive resemblances in music are not necessarily actual expressions of any genuinely occurring emotion.

${ }^{30)}$ So Angeli 2004, 15-16, 19. 
does, and comprehending words, a rational process which may inspire thought. ${ }^{31)}$ These experiences remain ontologically distinct even though we have both simultaneously when we hear poetry sung. So artists like Pindar and Simonides, says Philodemus, affect us in two

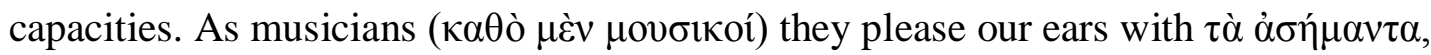

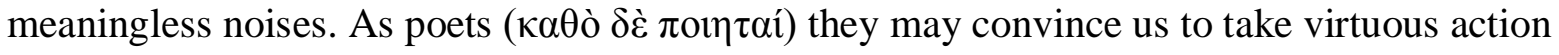
using $\lambda$ ó $\gamma o 1$, meaningful words. ${ }^{32)}$

These being his philosophical commitments, Philodemus must account for the fact that when actual soldiers hear trumpet blasts, they really do respond by going to battle. On the face of it this looks like pure musical sound prompting voluntary action. But, replies Philodemus, soldiers are already cowardly or brave: the intervallic patterns produced by the $\sigma \alpha ́ \lambda \pi 1 \gamma \xi$ do not make them act virtuously if they would not otherwise (Mus. 4.LXVIII.33-40). In fact, trumpets on the battlefield do not function as musical instruments at all. Instead, the trumpet's sound, like a vocal utterance ( $\varphi \omega v \eta ́)$, is a $\sigma \eta \mu \varepsilon \tilde{i o v} \dot{\varepsilon} \xi \dot{v} \pi \circ \lambda \dot{\eta} \psi \varepsilon \omega \varsigma$ (LXIX.7-12).

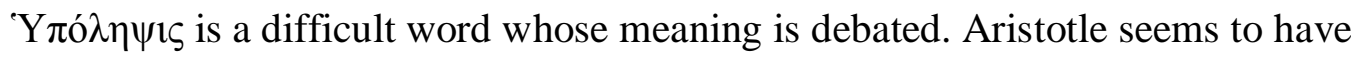
coined the relevant usage of the term as a catch-all for various kinds of cognitive judgment. ${ }^{33)}$

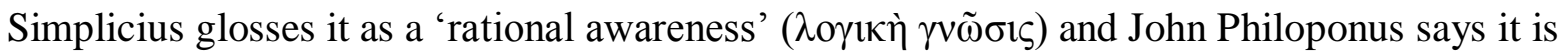

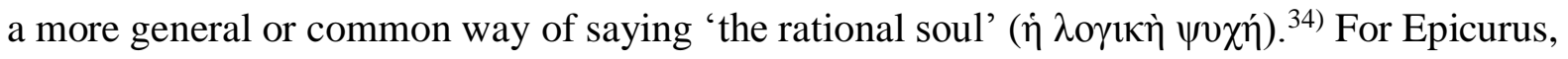

31) See Phld. Mus. 4.LXXXIV.30-37, XCII.1-5, CXII.33-42, CXXXIII.19-26, CXLVII.6-11; Kramarz 2016, 285f.

32) Phld. Mus. 4.CXLIII.11-39.

${ }^{33)}$ See Arist. De An. 427b24-6 (cf. Metaph. 981a1-12) with Chase 2010, 386f.; Shields 2016, 279f.

34) Simplicius in Arist. De An. 427b16; Philoponus in Arist. De An. 427b24. 


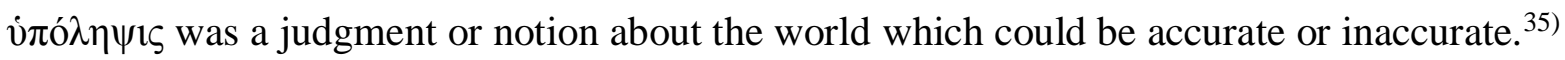
Philodemus duly uses it in this way also. ${ }^{36)} \mathrm{Y} \pi \mathrm{\pi} \lambda \hat{\eta} \psi \varepsilon \varepsilon \varsigma$ for him are often false, but not necessarily: their salient feature, mentioned explicitly in On Music, is that they are rational

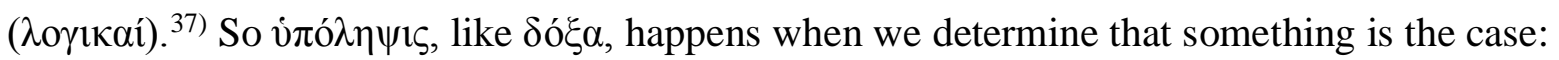
when I see a Snickers bar, there arise in my mind certain judgments, such as that it looks delicious and I want to eat it. Those, as I understand it, are vं $\pi \circ \lambda \eta \dot{\psi \varepsilon \varepsilon 1 \zeta . ~}$

Philodemus argues that the military trumpet is used as a signifier ( $\sigma \eta \mu \varepsilon i o v)$ of

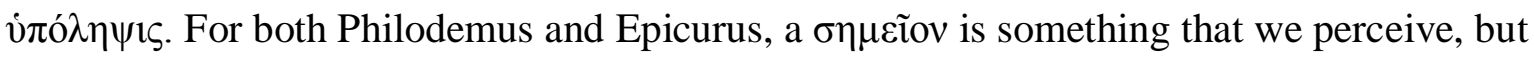
from which we can infer the existence or characteristics of something that we do not perceive (something from the realm of $\tau \grave{o} \alpha \ddot{\delta} \delta \eta \lambda \mathrm{ov}){ }^{38)}$ In this case the unperceived thing must be

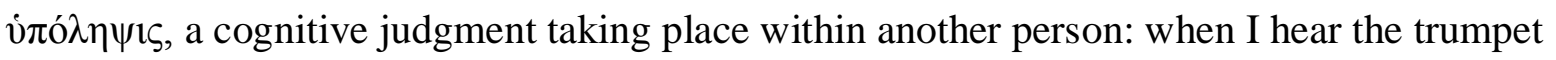
sound, I infer that my commander is thinking, 'it's time to attack.' This fits quite neatly into the Epicurean theory of language described in the Epistle to Herodotus. The relevant section is this one (75.6-6.7):

${ }^{35)}$ See Epicurus Ep. ad Men. 124 with Heßler 2014, 180 (and cf. Dyson 2009, 114f.); Diog. Laert. 10.34. We can see an example of this usage below (p. 16) in the Epistle to Herodotus, where the impersonal construction refers to something we must suppose about the historical formation of language without having witnessed it ourselves.

36) E.g. Phld. Piet. XLVI.1305-21, LXIA.1741-9, LXXI.2032-39 Obbink; Dis. 3.8.38 Diels.

37) Phld. Mus. 4.XCVII.35-41.

${ }^{38)}$ See Furley 1971, 612-7; De Lacy \& De Lacy 1978, 185-9; Asmis 1984, 176f., 190-6; 1999, 283-94; Allen 2008, 195-9, 226-41. For Philodemus' use of signs to infer about $\alpha$ $\delta \eta \lambda \alpha$ see esp. Phld. De Sig. I.1-19, XIV.2-27 De Lacy \& De Lacy. 


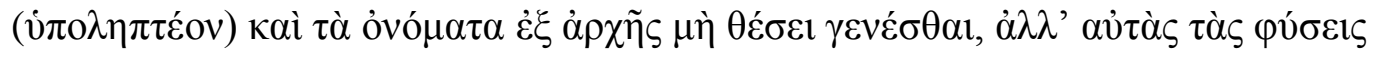

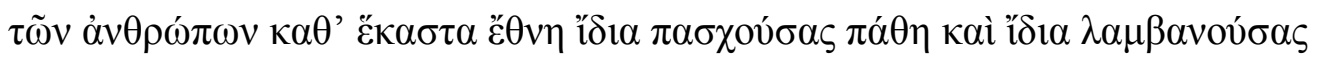

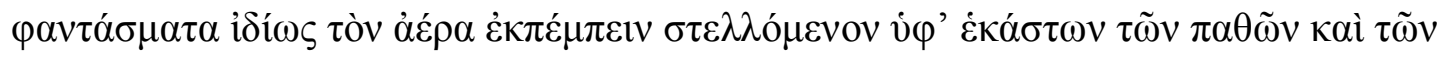

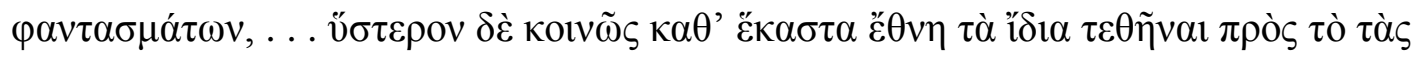

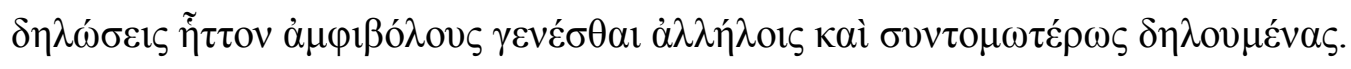

(We must suppose that) names, too, did not come about by convention at first, but that the very natures of people within each community, undergoing their own affections and receiving their own impressions, individually emitted breath that was arranged according to each of those affections and impressions .... Then later they assigned their own names together within each community with the goal of making their indications more succinct and less ambiguous to one another.

Names are the sounds we emit upon experiencing $\pi \alpha ́ \theta \eta$ and $\varphi \alpha v \tau \alpha ́ \sigma \mu \alpha \tau \alpha$, impressions made

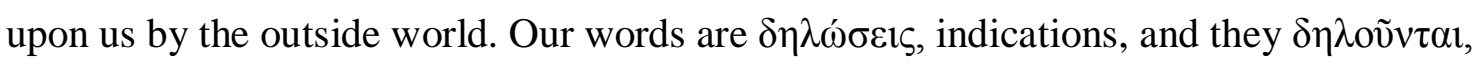
indicate. The word $\delta \hat{\eta} \lambda \omega \sigma ı \varsigma$ itself is not common in Epicurus' extant writings, but it fits easily into the Epicurean theory of $\sigma \eta \mu \varepsilon i ́ \omega \sigma ı \varsigma$ just described, wherein signs are perceptible things that tell us about $\alpha \varnothing \delta \eta \lambda \alpha$, imperceptible things. ${ }^{39)}$ So for words to be $\delta \eta \lambda \omega ́ \sigma \varepsilon ı \varsigma$ must mean that they are sounds which make perceptible to others what is otherwise ö $\delta \eta \lambda$ ov: our imperceptible internal cogitations. At first these verbal sounds are emitted naturally in response to individuals' experiences of the world (their ífí $\alpha$ jó $\theta \eta$ and $\varphi \alpha v \tau \alpha \dot{\sigma} \sigma \mu \alpha \tau \alpha)$. So perhaps when I see the Snickers bar I impulsively blurt out, 'mmmm!' But eventually communities of individuals agree together on a standardised set of sounds that will more

${ }^{39)}$ Cf. Diog. Laert. 10.32.8-11; Epicurus Ep. ad Men. 38.1-8. 
reliably and precisely denote thoughts. ${ }^{40)}$ So now our particular tribe can agree together that I should represent my experience of the Snickers to you using the sounds 'that looks delicious, give it here.'

The trumpet as used in battle is for Philodemus merely a special case of this second, later kind of conventionally assigned sonic communication. A group of soldiers agrees together that certain sounds will stand in for certain thoughts. Among those sounds will be

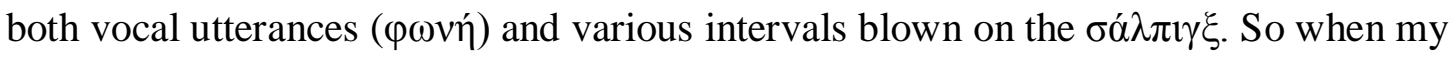
commander thinks 'it's time to attack,' he can either shout 'charge!' or blow a particular series of trumpet notes. Either sound is meaningless in itself, but comes to have meaning when members of a certain community - in this case, members of an army — come to

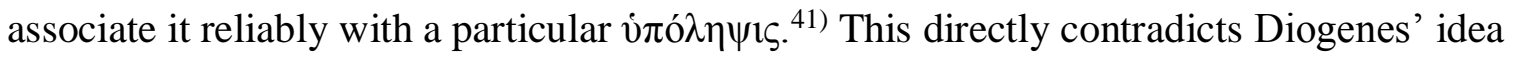
that certain kinds of melodies and rhythms just inherently possess ethical structures which we

40) The issue of how different the sounds initially emitted are between tribes, and whether their differences depend on different environmental experiences or differing racial makeups, is unclear and controversial (see Brunschwig 1977; Long \& Sedley 1987, 1.100f., 2.98). So is the degree to which our initial utterances change when we learn to refine them by convention (see Sedley 1973, 19; Schenkeveld \& Barnes 1999, 179f.; Holmes 2005, 557-60; Reinhardt 2008, 128f., 137f.; Stevens 2008, 532f.; Mackey 2015, 72f.; and cf. Lucretius, DRN 4.549-62, 5.1028-90; Cole 1967, 62). What is certain is that the first stage of language is generated by impulse, not intentional assignment (cf. Diogenes of Oenoanda fr. 12.II.8-V.14 Smith), whereas humans learn at a later time to assign sounds to thoughts by convention.

${ }^{41)}$ Cf. Phld. Mus. 4.LXVI.45-LXVII.11: music arouses people to religious revelry not because it entrances them spiritually, but because it signals the start of worship $\delta \imath^{\prime} \dot{v} \pi \mathrm{o} \lambda \dot{\eta} \psi \varepsilon ı \varsigma$ [oủ] $\delta \grave{\varepsilon}$

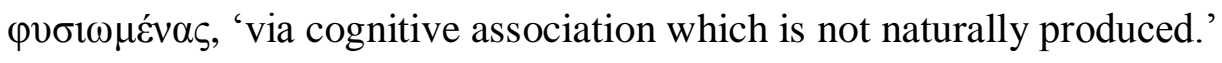




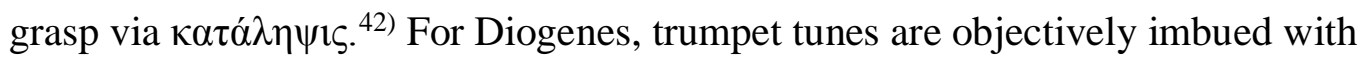
psychological impact. For Philodemus, they are simply arbitrary symbols assigned, like words, to stand in for thoughts.

\section{The context: ancient trumpets in literary and historical warfare}

Daniel Delattre compared Philodemus’ pronouncements with Aeneid 6.162-5, which gives this paper its title. The Trojan trumpeter Misenus is briefly eulogised in the wake of his undeserved death, and we are told that his tuba could 'move men' (ciere viros) and 'inflame Mars with song' (Martem accendere cantu). This sounds inescapably Diogenean: trumpet music instinctively rouses bloodlust and inspires soldiers to fight. There may even be a parallel between ciere and the Greek kıveiv, a standard term for the power of musical sound to rouse emotion. But, observes Delattre, Misenus is a special case: a preternaturally gifted musician whose talent surpasses the normal capacities of music. Vergil specifies elsewhere $(3.239,10.310)$ that in fact the trumpet is a military signal, signum. Vergil very likely knew Philodemus and studied Epicureanism. ${ }^{43)}$ So perhaps, though he made an exception for the exceptional Misenus, he was content elsewhere to concede Philodemus' point that the

42) This is why I do not find persuasive Angeli's (2004, 18f.) claim that assigning powers of signification to wordless trumpet tunes would essentially be admitting defeat for Philodemus, so that the views expressed in our passage must belong to Diogenes. My argument here is much more in agreement with that of Neubecker (1986, 134-6), whom Angeli aims to refute. 43) See above, n. 4 with P.Herc. Paris. 2 fr. 279a, and cf. e.g. Vergil's pointed reference at Ecl. 2.65 to Lucretius, DRN 2.258 (with Fowler 2002, ad loc.). But see further the caveat, wisely posed by Farrell (2014, 88-90), following and augmenting Horsfall 1995, 82; Cairns 2004, 314 , against reading too much into such allusions. 


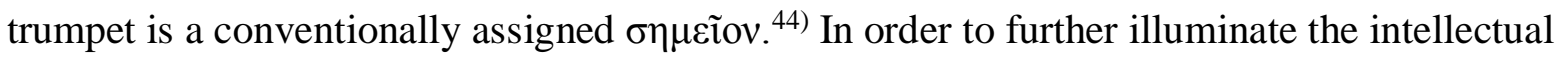
framework within which Diogenes and Philodemus were operating, I will now supplement Delattre's reference with some passages from archaic and classical Greek poetry in which the trumpet's semantic and musical properties feature prominently. Both theorists were conversant in the Hellenic poetic tradition that preceded them, ${ }^{45)}$ and understanding how the trumpet features in that tradition will help us understand what kind of instrument they were imagining when they proposed their respective theories.

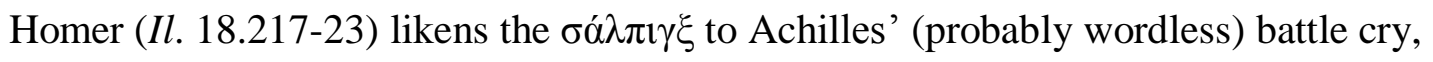

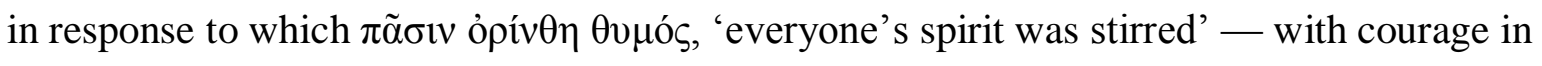
the case of the Greeks; with terror, military disorder, and flight in the case of the Trojans. ${ }^{46)}$ This might sound like score two for Diogenes: another instance in which the trumpet's pure musical sound generates an emotional response and consequent set of actions. But we should remember that Philodemus thinks any sound, including a non-verbal $\varphi \omega v \eta ́$, can stand in for a thought if those hearing and uttering it all agree that it is to be so interpreted. That could also be how the $\sigma \alpha \dot{\lambda} \lambda \pi \gamma \xi \xi$ functions in the Eumenides (566-9), where Athena instructs a herald to blast the signal for quiet in the house, or at Troades $1265-9$, where the instrument is actually

44) Delattre 2004, 254f.

${ }^{45)}$ See for example the minute analyses of citations from Homer, Timotheus, and Euripides in which Philodemus engages at Po. 1.LXXXIX.5-CX.9. Cf. P.Herc. 1676 VI.27-VII.7.

46) The trumpet (and paean-hymns) are greeted with similar terror among the barbarian forces at Aesch. Pers. 388-95 — the sound is said to have 'inflamed' ('̇ $\pi \dot{\varepsilon} \varphi \lambda \varepsilon \gamma \varepsilon v$ ) those who heard it with fear, as a result of the high spirits and readiness for battle which it expressed on the part of the Greeks (see Garvie 2009, 193). The trumpet is also used as a rousing call to battle alongside a paean at Eur. Pho. 1102 (see Mastronarde 1994, 456). 
said to participate in the enactment of a $\lambda$ ó $\gamma$ os (here a military order) ${ }^{47)}$ Finally, Athena herself was sometimes called $\sigma \alpha ́ \lambda \pi \imath \gamma \xi$, and in Sophocles' Ajax (14-7) her voice is compared with a trumpet call. ${ }^{48)}$ This simile is applied not to inchoate war-cries but to articulate speech,

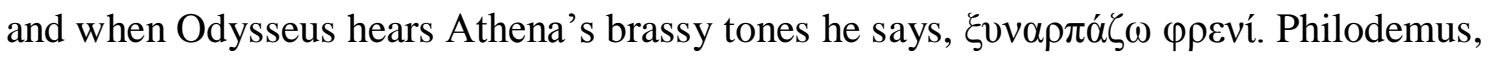
were he alive today, could translate this as P.J. Finglass (2011) and many others do, with some version of 'I grasp (your meaning) with my mind.' ${ }^{49)}$ Diogenes, though, would prefer Storr's (1913) rendering: 'those accents strike my ear and thrill my soul.' The ambiguity is telling. In the main, these passages seem to me to favour the Diogenean idea that the trumpet's emotional resonance results from an objective correspondence between its musical tonality and the disposition of the soul. But a committed Philodemean apologist might discern a pattern of poetic associations between the trumpet and verbal language, both of which function as conventional signifiers for a speaker's thoughts.

Such a defender of Philodemus might also point out that ancient military tacticians really did assign meaning to trumpet signals much in the way the Epicurean indicates,

47) On the other hand, commentators have noted the onomatopoetic imitation of the trumpet's sound in the Eumenides passage (see Egan 1979, 203-12), and the use of syllables to mimic the trumpet recurs elsewhere (see Enn. Ann. 450-1 Skutsch; Pöhlmann \& West 2001, 8 on Eleusis Inv. 907). This might suggest that the instrument's sound itself, not just the orders it happened to deliver, was distinctive and striking.

48) On the myth linking the goddess to the instrument and the resultant epithet see Paus.

2.21.3; Lycophron Alexandra 915, 986; Tz in Lycophron 915; $\Sigma$ Lycophron 986; $\Sigma$ Il. 18.218; Stanford 1963, 57; Hornblower 2015, 345.

49) See Finglass 2011, 142; Garvie 1998, $125 f$. 
choosing different note sequences for reveille, armament, attack, et cetera. ${ }^{50)}$ Roughly two centuries after Philodemus, Flavius Arrianus writes that one can make announcements in the

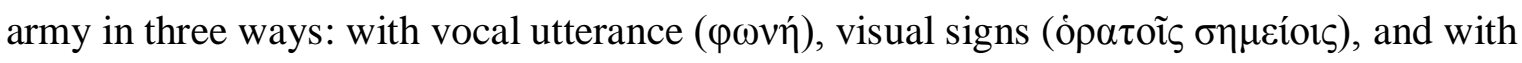
the trumpet - nonverbal symbols lack precision, but can cut across the din of battle. ${ }^{51)}$ Aristides Quintilianus asserts that trumpet calls are incomprehensible to enemy forces who do not know their assigned meanings, and the Peripatetic author of the De Mundo reflects that each soldier responds differently to the same trumpet call when each has been instructed about what that call must signify to him. ${ }^{52)}$ Xenophon confirms that these meanings can be reassigned at will when he tells us how he tricked the enemy by commanding his men to run when they heard the signal usually used for 'attack.' ${ }^{53)}$ All of this basically conforms to Philodemus' claim: soldiers agree together which note sequences to assign to various ideas, thus encoding a makeshift language into otherwise senseless sound.

\section{Conclusions: what the trumpet tells us}

All of this contextual information can help both to frame and to answer the most interesting question raised by the De Musica passage with which we began. That question is: what features of the trumpet, in its historical usages or literary appearances, made it important enough for both Philodemus and Diogenes to devote time, attention, and ink to it?

50) See Pritchett 1971, 105-8; Hanson 1989, 99; Krentz 1991, 114-7; West 1992, 118f.;

Barker 1996, 1003; Hale 2003, 267-73; Hornblower 2008, $185 f$.

51) Arr. Tact. 27.1-4 DeVoto. cf. Asclep. Tact. 12.10; All. Tact. 35.2; Ammianus 27.10.12;

Xen. A. 5.2.14, 6.5.27.

52) Arist. Quint. De Mus. 62.6-19; [Arist.] De Mundo 399b2-10.

53) Xen. A. 4.3.29-32; cf. Anderson 1970, 79-83. 
The answer lies in the arresting ambiguity of the military trumpet's essence, purpose, and function. This ambiguity raises three more questions, or perhaps one more question phrased three ways, which are central to ancient philosophy about music. First, what is music? Second, what counts as a musical instrument? Third, what can music do to the people who hear it?

My first question is anachronistically phrased. Its subject, the English 'music,' famously has no neat counterpart in the dynamic Greek and Latin tradition of describing what happens when sound becomes art. ${ }^{54)}$ Poetic song for Plato and Aristotle is a tripartite blend of three things which I will translate as verbal language ( $\lambda$ ójos), tonal arrangement ( $\dot{\alpha} \rho \mu$ ví́ $\left.^{\prime}\right)$, and rhythmically structured time $(\dot{\rho} v \theta \mu o ́ \varsigma) .{ }^{55)}$ Similarly Pseudo-Plutarch's Soterichus,

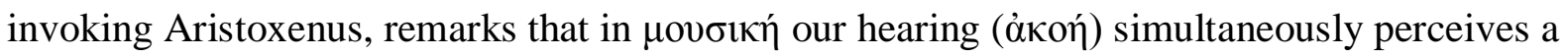
pitch ( $\varphi \theta$ ó $\gamma \gamma \sigma \varsigma)$, a duration ( $\chi \rho o ́ v o \varsigma)$, and a letter or syllable ( $\gamma \rho \alpha ́ \mu \mu \alpha$ or $\sigma v \lambda \lambda \alpha \beta \hat{)})$ united in one sound. ${ }^{56)}$ Trumpet calls have $\alpha \rho \mu o v i ́ \alpha$ and $\dot{\rho} v \theta \mu$ ó $\zeta$ but not $\lambda$ ó $\gamma$ os in the sense of verbal language; that is, they lack $\lambda \varepsilon^{\prime} \xi 1 \varsigma, \gamma \rho \alpha \dot{\mu} \mu \alpha \tau \alpha$, and $\sigma v \lambda \lambda \alpha \beta \alpha i$. But in military contexts they do convey semantic meanings. Philodemus thinks this makes them language and not music because he wants to claim, contra all the theorists I just mentioned, that there is something called language, $\lambda$ ó $\gamma o$ — defined by its possession of semantic properties — which is

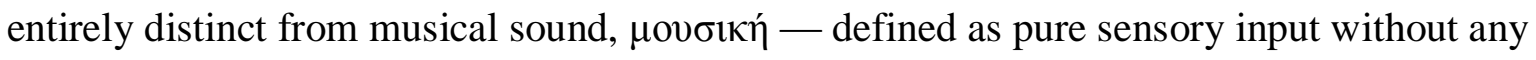

54) On this point see e.g. Murray \& Wilson 2004, 1-6; Woodward 2010, 236, 244f.; Rotstein 2012, 94; Brüllmann 2013, 349f.; D’Angour 2015, 188-90. Cf. West 1981, $113 f$. 55) See Pl. R. 398d1-3 (and cf. Gorg. 501d7-2b8); Arist. Po. 1447a13-23.

56) [Plu.] De Mus. 1144a8-b2 with Barker 2007, 236-9. On the Aristoxenian pedigree of this passage see Lasserre 1954, 102f., 175f.; Meriani 2003, 51-5; Rocconi 2005, 296 with n. 26; Barker 2013, 402 with n. 6. 
significance attached. Consequently even melody and rhythm, if they are used as $\sigma \eta \mu \varepsilon \tilde{\alpha} \alpha$, are

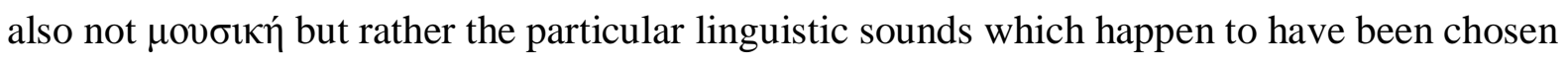
on this occasion to convey meaning.

So is the trumpet a musical instrument? Modern studies of the $\sigma \alpha \dot{\lambda} \pi \mathrm{\imath} \gamma \xi$ and the $t u b a$ often note that the extant examples of both seem designed to maximise communicative efficacy and not artistic merit: some probably could not even play a full scale. ${ }^{57)}$ The trumpet sounds hideous according to Pollux; according to Aristotle it sounds like an elephant. ${ }^{58)}$ Comparing the pipes to the trumpet, Marcus Cornelius Fronto says, minus est soni, plus difficultatis, implying that performance instruments have an ornate sound, but military trumpets just need to be loud. ${ }^{59)}$

Yet Horace says something different: the double-pipe (tibia) was originally thin and simple but has now become tubae aemula, a rival to the trumpet — while, and perhaps because, the Romans have developed an appetite for greater musical complexity and volume. ${ }^{60)}$ There were competitions in trumpet-playing that may well have been judged on aesthetic criteria, and Plutarch describes a $\sigma \alpha \dot{\lambda} \pi \iota \gamma \xi$ song which includes all manner of flourishes $(\kappa \rho \circ v ́ \mu \alpha \tau \alpha)$ and modulations $(\mu \varepsilon \tau \alpha \beta \circ \lambda \alpha i){ }^{61)}$ The author of the pseudo-Aristotelian treatise On Things Heard suggests that the trumpet's tone could be modified to fit the atmosphere ő $\alpha v \kappa \omega \mu \alpha ́ \zeta \omega \sigma \mathrm{v}$ - that is, it could be mood music for a raucous celebration. ${ }^{62)}$

57) See Krentz 1991, 112; West 1992, $118 f$.

58) Pollux 4.85.1-86.1; Arist. Hist. An. 536b20-3.

59) Epistulae ad M. Caesarem et Invicem III.1.

${ }^{60)}$ See Ars 202-11 with further comments by Brink 1971, 262-9.

${ }^{61)}$ See Plu. De Soll. An. 973b7-e4; Pollux 4.88; Krentz 1991, 113.

62) [Arist.] Aud. 803a24-7. 
Depending on which ancient source you consult, then, you will find that the trumpet's sound is either monotonously offensive or appealingly versatile. This speaks to the question, what is it for? Is it an artistic instrument or a utilitarian communications device, and what qualities, be they aesthetic or structural, determine the answer?

Lastly, and most importantly for Philodemus and Diogenes: if the trumpet does make music, what does that mean about how music affects its audience? Or rather, given that the trumpet makes people adopt certain behaviours, does that qualify or disqualify it as a musical

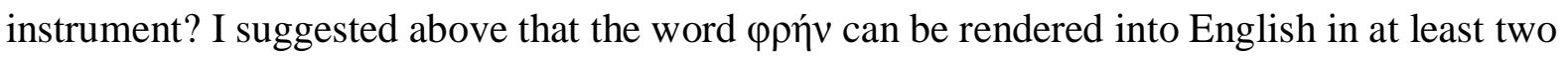
ways: as the 'heart' which feels and perceives, or as the 'mind' which comprehends, judges, and decides. But that too is an anachronism. There is one word for both in Greek because these features of human consciousness - qualitative sensation and propositional intellection — are irreducibly entangled in much ancient thought just as they are in much modern experience. Music engages our senses, sways our moods, and may even influence our actions. ${ }^{63)}$ The $\tilde{\eta} \theta$ o $\varsigma$ theories to which Diogenes is heir inevitably account for this fact by somehow framing the ear and the mind as co-operators, mapping out an intricate web of relationships between what we hear, feel, think, and do when we listen to music. But

63) The capacity of music to trigger neurological responses even in those who do not understand the language of a song's words, or who cannot do so because they are unconscious or semiconscious, is currently being shown quite convincingly by neuroscience: see O'Kelly et al. 2013; Mehr et al. 2018. 'H Hos theory has fallen out of fashion in many of its details, but its main thesis is not unlike others which do have serious currency in modernity — see Scruton 2009, 49-56 and above, nn. 13, 29. At any rate there can be little doubt that music's influence upon ethical attitudes and cultural mores remains a source of anxiety: for one highly influential treatment, see Bloom 1987, 68-81. 
Philodemus wants to preserve the distinctions between thought and perception so rigidly that he must sever entirely (and, in my view, quite mistakenly) the sound of a tune from the meaning of its words. The trumpet lies right on the hazy borderlines between music and language, between sense and thought, between the aesthetic and the semantic properties of sound. That is why it becomes such a live issue for both Diogenes and Philodemus as they puzzle over what music is and does. 


\section{Bibliography}

Algra, K. (2003). Stoic Theology. In: B. Inwood, ed., The Cambridge Companion to the Stoics, Cambridge: Cambridge University Press, pp. 153-78.

Allen, J. (2008). Inference from Signs. Oxford: The Clarendon Press.

Anderson, J.K. (1970). Military Theory and Practice in the Age of Xenophon. Berkeley: University of California Press.

Angeli, A. (2004). La musica e l'ethos guerriero in Filodemo, Sulla musica IV coll. 58-59 D. (PHerc. 1578 N 17-1575 N 18). SEP 1, pp. 11-20.

Annas, J. (1990). Stoic Epistemology. In: S. Everson, ed., Epistemology (Companions to Ancient Thought v3), Cambridge: Cambridge University Press, pp. 184-203.

Armstrong, D. (2004). Introduction. In: D. Armstrong, ed., Vergil, Philodemus, and the Augustans, Austin: University of Texas Press, pp. 1-22.

Asmis, E. (1984). Epicurus’ Scientific Method. Ithaca: Cornell University Press.

Asmis, E. (1992). Neoptolemus and the Classification of Poetry. CPh 87, pp. 206-31.

Asmis, E. (1999). Epicurean Epistemology. In: K. Algra, J. Barnes, J. Mansfeld, and M. Schofield, edd., The Cambridge History of Hellenistic Philosophy, Cambridge: Cambridge University Press, pp. 260-94.

Barker, A.D. (1984-9). Greek Musical Writings. Cambridge: Cambridge University Press.

Barker, A.D. (1991). Aristoxenus' Harmonics and Aristotle's Theory of Science. In: A.C. Bowen, ed., Science and Philosophy in Classical Greece, New York: Garland, pp.188-226.

Barker, A.D. (1996). Music. In: S. Hornblower, and A. Spawforth, edd., The Oxford Classical Dictionary, $3^{\text {rd }}$ ed., Oxford: Oxford University Press, p. 1003.

Barker, A.D. (2001). Diogenes of Babylon and Hellenistic Musical Theory. In: C. AuvrayAssayas and D. Delattre, edd., Cicéron et Philodème, Paris: Rue d'Ulm, pp. 353-70. 
Barker, A.D. (2005). The Journeying Voice. Apeiron 38, pp. 161-84.

Barker, A.D. (2007). The Science of Harmonics in Classical Greece. Cambridge: Cambridge University Press.

Barker, A.D. (2013). The Laws and Aristoxenus on the Criteria of Musical Judgment. In: A.E. Peponi (ed.), Performance and Culture in Plato's Laws, Cambridge, Cambridge University Press, pp. 392-416.

Bloom, A. (1987). The Closing of the American Mind. New York: Simon \& Schuster.

Brancacci, A. (1996). Diogene di Babilonia e Aristosseno nel De Musica di Filodemo. In: G.

Giannantoni and M. Gigante, edd., Epicureismo greco e romano, Naples: Bibliopolis, pp. 573-83.

Brink, C.O. (1971). Horace on Poetry: The 'Ars Poetica'. Cambridge: Cambridge University Press.

Brüllmann, P. (2013). Music Builds Character. Apeiron 46, pp. 345-73.

Brunschwig, J. (1977). Epicure et le probleme du langage prive. Revue des sciences humaines 43, pp. 157-77.

Budd, M. (2003). Musical Movement and Aesthetic Metaphors. British Journal of Aesthetics 43, pp. 209-23.

Cairns, F. (2004). Varius and Vergil. In: D. Armstrong, ed., Vergil, Philodemus, and the Augustans, Austin: University of Texas Press, pp. 299-321.

Chase, M. (2010). Porphyry on the Cognitive Process. AncPhil 30, pp. 383-405.

Cole, T. (1967). Democritus and the Sfources of Greek Anthropology. Cleveland: Western Reserve University Press.

D’Angour, A. (2015). Sense and Sensation in Music. In: P. Destrée and P. Murray, edd., A Companion to Ancient Aesthetics, Chichester: Wiley-Blackwell, pp. 188-203.

Davies, S. (1994). Musical Meaning and Expression. Ithaca: Cornell University Press. 
De Lacy, P. and De Lacy, E.A. (1978). Philodemus: On Methods of Inference. Naples: Bibliopolis.

Delattre, D. (1989). Philodème, De la musique: livre IV, colonnes 40* à 109*. CErc 19, pp. 49-143.

Delattre, D. (1993). Speusippe, Diogène de Babylone et Philodème. CErc 23, pp. 67-86.

Delattre, D. (2004). Vergil and Music, in Diogenes of Babylon and Philodemus. In: D. Armstrong, ed., Vergil, Philodemus, and the Augustans, Austin: University of Texas Press, pp. 245-63.

Delattre, D. (2007). Philodème de Gadara: Sur la musique, livre IV. Paris: Les Belles Lettres.

Dolar, M. (2006). A Voice and Nothing More. Cambridge, Mass.: The MIT Press.

Dyson, H. (2009). Prolepsis and Ennoia in the Early Stoa. Berlin: De Gruyter.

Egan, R.B. (1979). The Assonance of Athena and the Sound of the Salpinx. CQ 74, pp. 20312.

Everson, S. (1990). Epicurus on the Truth of the Senses. In: S. Everson, ed., Epistemology (Companions to Ancient Thought v3), Cambridge: Cambridge University Press, pp. 161-183.

Farrell, J. (2014). Philosophy in Vergil. In: M. Garani, and D. Constan, edd., The Philosophizing Muse, Newcastle Upon Tyne: Cambridge Scholars Publishing, pp. 6190.

Ferguson, E. (2003). The Art of Praise. In: M.L. White, T.H. Olbricht, and J.T. Fitzgerald, edd., Early Christianity and Classical Culture, Leiden: Brill, pp. 391-426.

Finglass, P.J. (2011). Sophocles: Ajax. Cambridge: Cambridge University Press.

Fowler, D. (2002). Lucretius on Atomic Motion. Oxford: Oxford University Press. 
Frede, M. (1999). Stoic Epistemology. In: K. Algra, J. Barnes, J. Mansfeld, and M. Schofield, edd., The Cambridge History of Hellenistic Philosophy, Cambridge: Cambridge University Press, pp. 295-322.

Furley, D.J. (1971). Knowledge of Atoms and Void in Epicureanism. In: J.P. Anton and D.L. Kustas, edd., Essays in Ancient Greek Philosophy, v1, Albany: SUNY Press, pp. 60719 (= Furley, D.J. [1989] Cosmic Problems. Cambridge: Cambridge University Press, 161-71).

Garvie, A.F. (1998). Sophocles: Ajax. Warminster: Aris \& Phillips.

Garvie, A.F. (2009). Aeschylus: Persae. Oxford: Oxford University Press.

Gigante, M. (2004). Vergil in the Shadow of Vesuvius. In: D. Armstrong, ed., Vergil, Philodemus, and the Augustans, Austin: University of Texas Press, pp. 85-99.

Gigante, M., and Capasso, M. (1989). Il ritorno di Virgilio a Ercolano. SIFC 7, pp. 3-6.

Gomperz, T. (1885). Zu Philodem's Büchern von der Musik. Vienna: Alfred Hölder (= Gomperz, T. [1993]. Eine Auswahl herkulanischer kleiner Schriften. Leiden: Brill, pp. 113-61).

Gourinat, J.-B. (2009). The Stoics on Matter and Prime Matter. In R. Salles, ed., God and Cosmos in Stoicism, Oxford: Oxford University Press, pp. 46-70.

Hahmann, A. (2015). Epikur über den Gegenstand der Wahrnehmung. AGPh 97, pp. 271307.

Hale, J.R. (2003). 'Salpinx' and 'Saplinktes'. In: A.F. Basson, and W.J. Dominik, edd., Literature, Art, History, Frankfurt am Main: Peter Lang, pp. 267-73.

Halliwell, S. (1986). Aristotle's Poetics. London: Duckworth.

Halliwell, S. (2002). The Aesthetics of Mimesis. Princeton, New Jersey: Princeton University Press. 
Hanslick, E. (1922). Vom Musikalisch-Schönen, 13.-15. Auflage. Leipzig: Breitkopf \& Härtel (1st edition 1854).

Hanson, V.D. (1989). The Western Way of War. London: Hodder and Stoughton.

Heßler, J.E. (2014). Epikur: Brief an Menoikeus. Basel: Schwabe.

Holmes, B. (2005). Daedala Lingua. AJPh 126, pp. 527-85.

Hornblower, S. (2008). A Commentary on Thucydides, v3. Oxford: Oxford University Press.

Hornblower, S. (2015). Lykophron: Alexandra. Oxford: Oxford University Press.

Horsfall, N. (1995). A Companion to the Study of Virgil. Leiden: Brill.

Ierodiakonou, K. (2014). The Stoic System: Logic and Knowledge. In: J. Warren and F.

Sheffield, edd., The Routledge Companion to Ancient Philosophy, New York:

Routledge, pp. 438-54.

Janko R. (1992). A First Join between P. Herc. $411+1583$ (Philodemus, On music IV). CErc 22, pp. 123-129.

Janko, R. (2000). Philodemus: On Poems Book 1. Oxford: Oxford University Press.

Janko, R. (2011). Philodemus: On Poems Books 3-4, with the Fragments of Aristotle, On Poets. Oxford: Oxford University Press.

Kahn, C.H. (1969). Stoic Logic and Stoic LOGOS. AGPh 51, pp. 158-72.

Kaklamanou, E. (2012) 'Speusippus on Cognitive Sense Perception,' British Journal for the History of Philosophy 20: 1183-93.

Kerferd, G. (1978). The Problem of Synkatathesis and Katalepsis in Stoic Doctrine. In: J. Brunschwig, ed., Les Stö̈ciens et leur logique, Paris: Librairie Philosophique J. Vrin, pp. 251-72.

Kivy, P. (1980). The Corded Shell. Princeton, New Jersey: Princeton University Press. Kramarz, A. (2016). The Power and Value of Music. New York: Peter Lang. 
Krentz, P.M. (1991). The Salpigx in Greek Warfare. In: V.D. Hanson, ed., Hoplites, London: Routledge, pp. 110-20.

Langer, S. (1941). Philosophy in a New Key. Cambridge, Mass.: Harvard University Press.

Lasserre, F. (1954). Plutarque: De la musique. Lausanne: Urs Graf Verlag.

Levin, F.R. (2007). Apeiria in Aristoxenian Theory. Hermes 135, pp. 406-28.

Long, A.A. (1971). Language and Thought in Stoicism. In: A.A. Long, ed., Problems in Stoicism, London: The Athlone Press, pp. 75-113.

Long, A.A. (2002). Zeno's Epistemology and Plato’s Theaetetus. In: T. Scaltsas and A.S. Mason, edd., The Philosophy of Zeno, Larnaka: Municipality of Larnaka, pp. 113-32. Long, A.A., and Sedley, D.N. (1987). The Hellenistic Philosophers. Cambridge: Cambridge University Press.

Mackey, J.L. (2015). New evidence for the Epicurean Theory of the Origin of Language. CErc 45, pp. 67-84.

Mastronarde, D.J. (1994). Euripides: Phoenissae. Cambridge: Cambridge University Press. Matelli, E. (2004). Musicoterapia e catarsi in Teofrasto. BICS 47, pp. 153-174.

Mehr, S.A., Singh, M., York, H., Glowacki, L., and Krasnow, M.M. (2018). Form and Function in Human Song. Current Biology 28, pp. 1-13.

Meriani, A. (2003). Sulla musica greca antica. Naples: Guida.

Murray, P., and Wilson, P. (2004). Introduction. In: P. Murray and P. Wilson, edd., Music and the Muses, Oxford: Oxford University Press, pp. 1-8.

Neubecker, A.J. (1986). Über die Musik IV. Buch. Naples: Bibliopolis.

Nussbaum, M. (1993). Poetry and the Passions. In: J. Brunschwig and M. Nussbaum, edd., Passions and Perceptions. Cambridge: Cambridge University Press, pp. 97-149.

Obbink, D. (1999). The Stoic Sage in the Cosmic City. In K. Ierodiakonou, ed., Topics in Stoic philosophy, Oxford: Oxford University Press, pp. 178-195. 
Obbink, D., and Vander Waerdt, P.A. (1991). Diogenes of Babylon. GRBS 32, pp. 355-39.

O’Keefe, T. (2014). Epicurus' Garden: Physics and Epistemology. In: J. Warren and F.

Sheffield, edd., The Routledge Companion to Ancient Philosophy, New York:

Routledge, pp. 455-68.

O’Kelly, J., James, L., Palaniappan, R., Taborin, J., Fachner, J., and Magee, W.L. (2013).

Neurophysiological and Behavioral Responses to Music Therapy in Vegetative and Minimally Conscious States. Frontiers in Human Neuroscience 7, p. 884.

Parente, M.I. (1980). Speusippo: Frammenti. Naples: Bibliopolis.

Pelosi, F. (2010). Plato on Music, Soul and Body. Cambridge: Cambridge University Press.

Petraki, Z. (2008). The Soul 'Dances'. Apeiron 41, pp. 147-70.

Pöhlmann, E., and West, M.L. (2001). Documents of Ancient Greek Music. Oxford: Clarendon Press.

Pritchett, W.K. (1971). The Greek State at War, Part I. Berkeley: University of California Press.

Reinhardt, T. (2008). Epicurus and Lucretius on the Origins of Language. CQ 58, pp. 127-40.

Rispoli, G. (1974). Filodemo sulla musica. CErc 4, pp. 57-87.

Robinson, J. (2005). Deeper than Reason. Oxford: Oxford University Press.

Rocconi, E. (2005). La dottrina aristossenica dell' ethos musicale nel de musica dello Ps.Plutarco. SemRom 8, pp. 291-7.

Rotstein, A. (2012). Mousikoi Agones and the Conception of Genre in Ancient Greece. ClAnt 31, pp. 92-127.

Scade, P. (2017). Music and the Soul in Stoicism. In: R. Seaford, J. Wilkins, and M. Wright, edd., Selfhood and the Soul, Oxford: OUP, pp. 197-216. 
Schenkeveld, D.M., and Barnes, J. (1999). Language: Poetics. In: Algra, K., ed., The Cambridge History of Hellenistic Philosophy, Cambridge: Cambridge University Press, pp. 221-5.

Scruton, R. (2009). Understanding Music. London: Continuum.

Sedley, D. (1973). Epicurus: On Nature, Book XXVIII CErc 3, pp. 5-83.

Shields, C.J. (2016). Aristotle: De Anima. Oxford: Clarendon Press.

Stanford, W.B. (1963). Sophocles: Ajax. London: Macmillan \& Co.

Stevens, B.E. (2008). Symbolic Language and Indexical Cries. CQ 129, pp. 529-57.

Storr, F. (1913). Sophocles, v2. Cambridge, Mass.: Harvard University Press.

Striker G. (1977). Epicurus on the Truth of Sense Impressions. AGPh 59, pp. 125-142.

Tarán, L. (1981). Speusippus of Athens. Leiden: Brill.

Taylor, A.E. (1928). A Commentary on Plato's Timaeus. Oxford: Clarendon Press.

Togni, P. (2013). Plato’s Soul-Book Simile and Stoic Epistemology. Méthexis 26, pp. 163185.

West, M.L. (1981). The Singing of Homer and the Modes of Early Greek Music. JHS 101, pp. 113-29.

West, M.L. (1992). Ancient Greek Music. Oxford: Clarendon Press.

White, M.J. (2003). Stoic Natural Philosophy (Physics and Cosmology), in B. Inwood, ed., The Cambridge Companion to the Stoics, Cambridge: Cambridge University Press, pp. 124-52.

Wittgenstein, L. (1980). Vermischte Bemerkungen/Culture and Value. Oxford: Basil Blackwell.

Woodward, L. (2010). Diogenes of Babylon Reading Plato on Music. In: V. Harte, M. M. McCabe, R. W. Sharples, and A. Sheppard, edd., Aristotle \& the Stoics Reading Plato, London: Institute of Classical Studies, pp. 233-53. 